\section{CITAÇÃO}

Castro, S., Loureiro, J. (2016)

A vida amorosa das plantas,

Rev. Ciência Elem., V4 (04):029.

doi.org/10.24927/rce2016.029

\section{EDITOR}

José Ferreira Gomes,

Universidade do Porto

\section{COPYRIGHT}

(C) Casa das Ciências 2016.

Este artigo é de acesso livre, distribuído sob licença Creative Commons com a designação CC-BY-NC-SA 4.0, que permite a utilização e a partilha para fins não comerciais, desde que citado 0 autor e a fonte original do artigo.

\section{rce.casadasciencias.org}

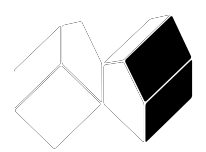

\title{
A vida amorosa das plantas
}

\author{
Sílvia Castro*, João Loureiro \\ Centro de Ecologia Funcional, - DCV e Jardim Botânico da Universidade de Coimbra \\ *scastro@bot.uc.pt
}

"Sexual reproduction is just as important for plants as it is for animals when it comes to generating genetic variation, but plants have a singular disadvantage compared to animals when it comes to sex: they can't just get up and find themselves a mate."

Berenbaum (1995)

\section{0 que nos revela a morfologia de uma flor}

Quando caminhamos pela natureza ficamos maravilhados com a diversidade de formas, cores e odores que encontramos nas estruturas florais das Angiospérmicas. Esta diversidade não existe por acaso e cada estrutura surge como resultado de uma interação próxima entre a planta e o seu polinizador.

Como qualquer outro ser vivo, o principal objetivo de uma planta é reproduzir-se para dessa forma transmitir os seus genes à descendência. Neste processo existe um passo fundamental, a polinização, que consiste na transferência dos grãos de pólen desde as estruturas masculinas (anteras) até à estrutura feminina (papilas estigmáticas) onde encontram o ambiente propício para germinar e fertilizar os óvulos. No entanto, as plantas tem uma característica peculiar que as distingue dos animais, estão imóveis (não confundir com serem imóveis, porque na realidade são capazes de se mover através das suas sementes ou grãos de pólen). Assim, as plantas dependem de vetores que transportem os seus grãos de pólen até às papilas estigmáticas, chamados de vetores de polinização. Os vetores podem ser abióticos, como a água e o vento, mas na realidade cerca de $80 \%$ das plantas com flor é polinizada por vetores bióticos, i.e., animais dos mais variados grupos, incluindo insetos, aves, morcegos, roedores ou até répteis (FIGURA 1). A polinização é um mutualismo, mas esta interação mutualista é baseada em motivos egoístas: as plantas procuram ser polinizadas e os polinizadores procuram alimento, abrigo e/ou calor. Porque na natureza a competição é sempre feroz, as plantas necessitaram de desenvolver diversas estratégias para atrair e fidelizar os seus polinizadores, sendo que, normalmente, várias características funcionam em conjunto para alcançar este objetivo. 

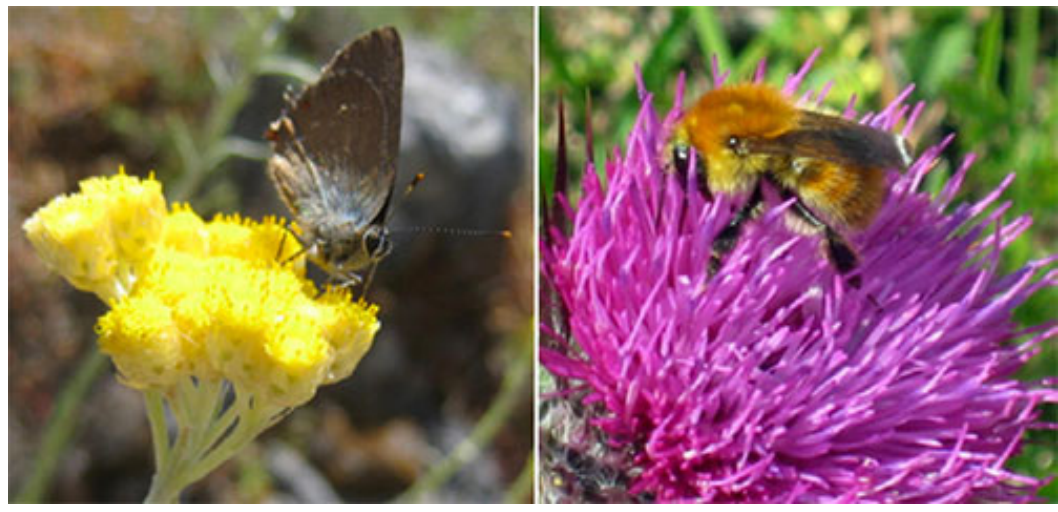

FIGURA 1. Exemplos de polinizadores: Lepidoptera e Bombus pascuorum (Apidea, Hymenoptera).

\section{Atividade: descobrir as histórias escondidas na flor}

Como seria de esperar, a estrutura de flores polinizadas por diferentes grupos de vetores ou com diferentes estratégias de reprodução será diferente. Explorar a morfologia da flor, não só reconhecendo e localizando cada componente mas também questionando a função da morfologia que apresentam é uma atividade de descoberta muito interessante e exequível com a diversidade de formas que existe na vegetação da nossa flora.

Por exemplo, plantas polinizadas pelo vento não necessitam de produzir estruturas para atrair um vetor que é imprevisível. Assim, as flores destas plantas são normalmente simples e sem pigmentação colorida. Exemplo disso são as gramíneas (às quais pertencem os cereais) nas quais as peças florais são geralmente verdes, as anteras excertas e pendulas (FIGURA 2), e estas produzem uma elevadíssima quantidade de pólen para aumentar a probabilidade deste chegar ao estigma de outra flor; os grãos de pólen são de pequenas dimensões para serem facilmente transportado através do vento. Por outro lado, os estigmas, também expostos, são geralmente plumosos para facilmente filtrarem os grãos de pólen do ar.

Em oposição encontramos as plantas polinizadas por animais. Nestas são esperadas recompensas florais, mais comummente pela produção de néctar em glândulas especializadas (i.e., nectários no interior da corola e na base do ovário; como exemplo temos as madressilvas) ou pela abundante produção de pólen (por exemplo na família das compostas ou as estevas e roselhas) (FIGURA 2), mas também sob a forma de óleos, calor ou até mesmo abrigo. Por exemplo, o género Serapias é um grupo de orquídeas que fornece abrigo aos insetos que pernoitam no interior da corola, transportando os grãos de pólen que aderem ao seu corpo no dia seguinte (FIGURA 2). Por sua vez, as madressilvas escondem o néctar na base de uma corola estreita e tubular, néctar esse que apenas pode ser colhido por insetos de aparelho bucal suficientemente fino e longo, como as borboletas (FIGURA 2). Odores, cores vistosas e padrões que somente são visíveis aos insetos (padrões com emissão no ultravioleta) são outras formas que as plantas com flor utilizam para se destacarem das demais e "chamarem" à atenção do polinizador. Por exemplo, a corola da dedaleira é marcada por um padrão de manchas que funcionam como sinalizadores de uma pista de aterragem. A morfologia pode atingir uma complexidade ainda maior, sendo exemplo disso as orquídeas do género Ophrys que mimetizam a forma das 
fêmeas de determinados insetos (FIGURA 2). A forma conjuntamente com a produção de odores semelhantes às hormonas sexuais, mimetizam na perfeição a parceira destes insetos, iludindo-os a visitar a flor e, consequentemente, a transportar o seu pólen.

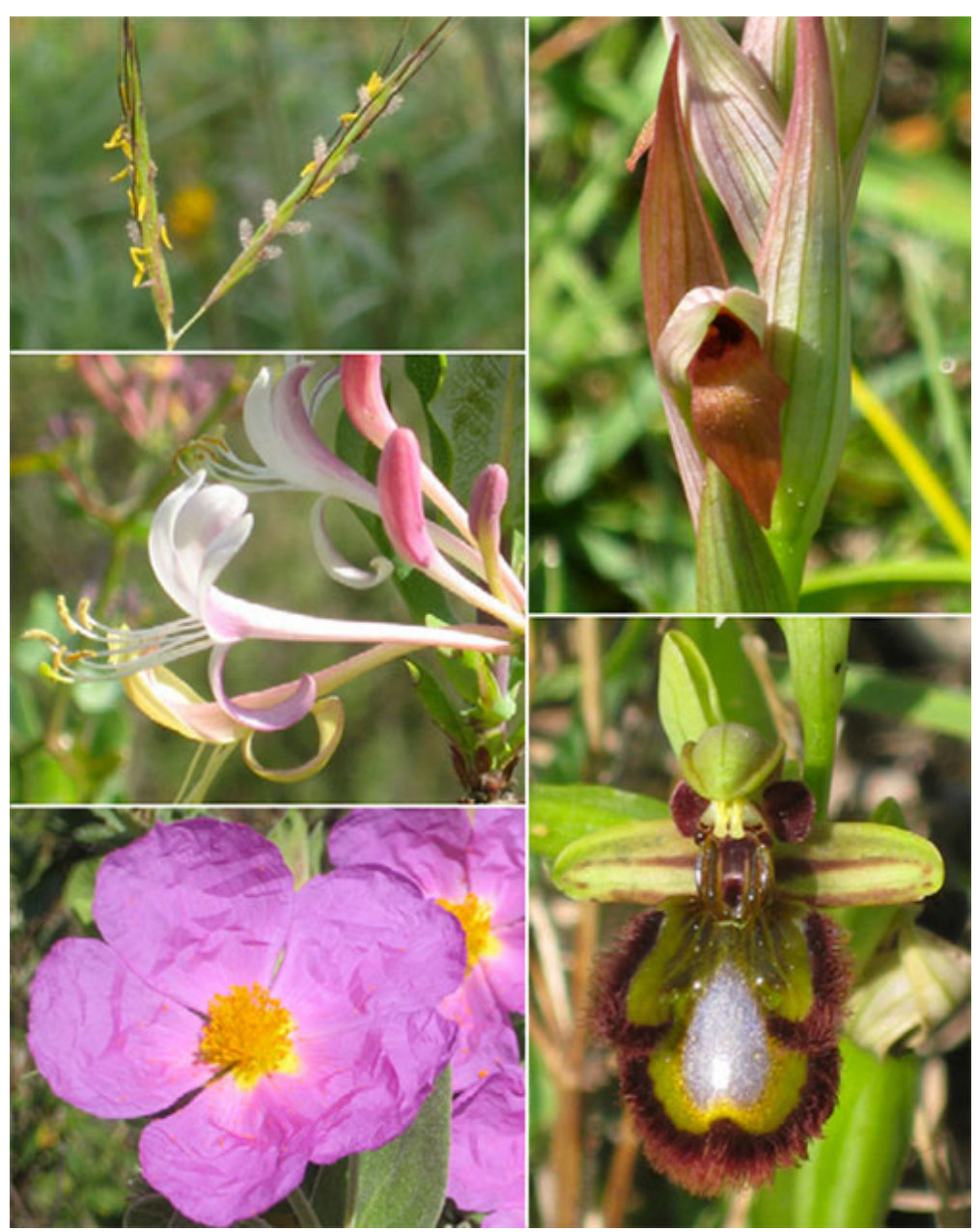

FIGURA 2. Diversidade de estruturas florais: gramínea com anteras (amarelas) e estigmas (brancos) expostos, madressilva (Lonicera etrusca), roselha-grande (Cistus albidus), erva-língua (Serapias sp.), Ophrys speculum.

Os grãos de pólen de plantas polinizadas por animais apresentam também morfologias particulares que podem ser facilmente observadas ao microscópio. Para permitir uma fácil adesão ao corpo dos insetos os grãos de pólen possuem, por exemplo, espinhos (morfologia típica da família das compostas; FIGURA 3) ou estão recobertos por substâncias lipídicas pegajosas. Podem ainda ser libertados em pacotes de várias unidades (por exemplo, tétradas presentes na família das urzes, FIGURA 3, ou mássulas maiores, as polínias, como nas orquídeas). As flores podem também estar organizadas em grandes conjuntos, as inflorescências, para aumentar a atratividade da planta, ou até mesmo para formar plataformas que permitam a aterragem dos polinizadores, como o que acontece nas umbelíferas ou nas compostas. 


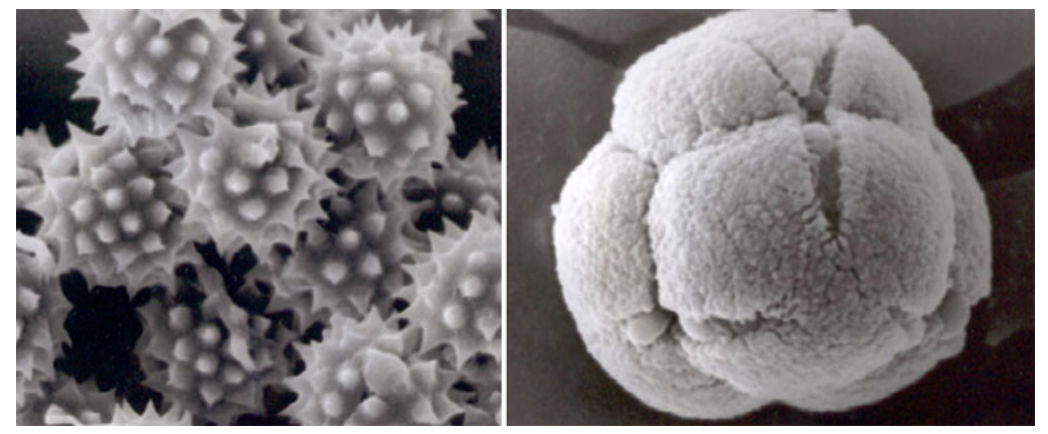

FIGURA 3. Exemplo de grãos de pólen: grãos com espinhos (Helichrysum sp., Compositae), e grãos agregados numa tétrada (Erica sp., Ericaceae)

Assim, como resultado das estreitas interações com os seus vetores de polinização e da sua capacidade ecológica e evolutiva as Angiospérmicas apresentam uma notável diversidade de formas. Conhecer a diversidade de formas e interações é fundamental para percebermos os mecanismos evolutivos geradores da diversidade que observamos assim como para desenvolver medidas adequadas para a sua conservação. Aqui fica apenas o início, existindo inúmeras estratégias mais... mas isso fica para a próxima história...

Fica o desafio: sair para a natureza e descobrir a diversidade das flores! 